ISSN : 2087-2461

PENANGGUNG JAWAB Dekan FIKOM

Trimanah, M.Si.

Sekretaris Dekan

Dian Marhaeni K, M.Si

Ketua Penyunting Made Dwi Adnjani, M.Si

Sekretaris

Mubarok, M.Si

Bendahara

Umi Hidayah, S.H.

Dewan Penyunting

Trimanah, M.Si

Edi Ismoyo, M.Si

Suharyoso, S.Sos

Seksi Usaha

Endang Winarsih, S.Sos

Sirkulasi dan Distribusi

Novi, S.Sos

Alamat Redaksi

Fakultas Ilmu Komunikasi

Universitas Islam

Sultan Agung Semarang

Jl. Raya Kaligawe Km. 4

Po. Box 1054/SM

Semarang 50112

Telp. (024) 6583584

ext. $448 / 449$

Fax. (024) 6582455

email : jurnalfikom@yahoo.com
Inovasi Digital Public Relations Pada

Perguruan Tinggi Swasta di Kota Semarang

dalam Meningkatkan Citra

Agus Triyono

agustriyono7@gmail.com

119-126

Eksistensi Buruh Dalam Komunikasi Bipartit

(Upaya Membangun Kemitraan Antara

Buruh dan Pengusaha Secara Ideal di Kota Kretek)

Muhammad Zakki Mubarok

$127-139$

Implementasi Konsep Diri Pada Kelompok Gemes

(Gemuk Menawan Semarang)

Kajian Teoritis Psikologi Komunikasi tentang

Konsep Diri Pada Kelompok Gemes

(Gemuk Menawan Semarang)

Genta Maghvira

140-149

Representasi Perempuan dalam

Film Cinta Suci Zahrana

Urip Mulyadi

$150-158$

Kapitalisme, Budaya Dunia, Internasionalisasi Bahasa dan Nilai-Nilai Islam Pada Tayangan Periklanan Anak di Media Televisi Dalam Perspektif Bidang Kreatif Industri Periklanan

Dian Marhaeni Kurdaningsih

marhaeni@unissula.ac.id

159-172

Paparan Media Promosi Kesehatan

Dengan Pengetahuan Pencegahan Infeksi

Bagi Pengunjung Rumah Sakit

Besar Tirto Husodo

e-mail : besarundip4@gmail.com

Puspa Run Canti

173-177

Model Kampanye Pilkada Atasi Politik Uang

dan Sikap Pesimis Pemilih

(Telaah teoritis dan konsep implementasinya)

Hariyani

nhyani812@gmail.com

178-193 


\title{
REPRESENTASI PEREMPUAN DALAM FILM CINTA SUCI ZAHRANA
}

\author{
Urip Mulyadi \\ Dosen Fakultas Ilmu Komunikasi Unissula
}

\begin{abstract}
Abstrak
Perbedaan gender adalah perbedaan yang dibangun secara sosial kultural, yang terkait dengan perbedaan status, sifat peran dan tanggung jawab antara laki-laki dan perempuan.Perbedaan status, sifat, peran dan tanggun jawab ini digambarkan dalam film Cinta Suci Zahrana yang diangkat berdasarkan novel karya Habiburahman El-Shirazy. Zahrana adalah seorang perempuan yang memiliki banyak prestasi, penghargaan dan berpendidikan tinggi. Namun dalam film ini diceritakan bahwa di usianya yang ke 34 tahun tokoh utama (Zahrana) belum mendapatkan jodoh. Sehingga membuat kedua orang tuanya merasa malu karena terdapat pembicaraan yang tidak enak tentang anaknya. Film ini lebih banyak menggambarkan bagaimana seorang perempuan yang berusaha mencari jodoh. Film memiliki potensi untuk mempengaruhi khalayaknya. Semiotika berusaha menjelaskan jalinan tanda atau ilmu tentang tanda, secara sistematik menjelaskan esensi, ciri-ciri dan bentuk suatu tanda, serta proses signifikansi yang menyertainya.Dalam hal ini penulis berusaha mencari makna denotasi, konotasi dan mitos yang bisa merepresentasikan perempuan dalam film Cinta Suci Zahrana.

Dalam Film ini membentuk beberapa representasi mengenai perempuan, bahwa pendidikan dan prestasi yang diraih tidak menjadi penting ketika perempuan belum bisa membangun rumah tangga atau menikah. Ideologi gender telah membentuk budaya patriarkal di masyarakat dan menciptakan male dominated culture, budaya yang didominasi oleh dan mengutamakan laki-laki sehingga memunculkan ketidakadilan. Film ini menunjukkan mitos bahwa sebaik-baik perempuan ialah yang dapat menjadi ibu rumah tangga yang baik. Bukan sebuah prestasi dan gelar yang tinggi. Kemudian perempuan yang benar-benar menjadi perempuan ialah perempuan yang bisa melahirkan dan mengasuh anak.
\end{abstract}

\section{Kata Kunci: Representasi Perempuan, Semiotika, Film}

\section{Pendahuluan}

Gender adalah konstruksi sosial, bukan sesuatu yang bersifat biologis. (Letty M Russel, 1996:124) Sehingga konsep gender mengacu pada perbedaan-perbedaan antara perempuan dengan laki-laki yang merupakan bentukan sosial. Perbedaan gender adalah perbedaan yang dibangun secara sosial kultural, yang terkait dengan perbedaan status, sifat peran dan tanggung jawab antara lakilaki dan perempuan.

Perbedaan status, sifat, peran dan tanggun jawab ini digambarkan dalam film Cinta Suci Zahrana yang diangkat berdasarkan novel karya Habiburahman ElShirazy. Zahrana adalah seorang perempuan yang memiliki banyak prestasi dan namanya mendunia karena karya tulisnya dimuat di jurnal ilmiah RMIT Melbourne. Dari karya tulis itu, Zahrana meraih penghargaan dari Thinghua University, sebuah universitas ternama di China. Ia pun terbang ke negeri Tirai Bambu untuk menyampaikan orasi ilmiah. Di hadapan puluhan profesor arsitek kelas dunia, ia memaparkan arsitektur bertema budaya. Yang ia tawarkan arsitektur model kerajaan Jawa-Islam dahulu kala. Dari Thinghua University, Zahrana mendapat tawaran beasiswa untuk studi S3 di samping mendapat tawaran pengerjaan sebuah proyek besar.

Namun Zahrana tidak hidup sendiri. Di tengah kesuksesan prestasi akademiknya, ia malah menjadi bahan kecemasan kedua orang tuanya. Kecemasan itu lantaran Zahrana belum juga menikah di usianya yang memasuki 
kepala tiga. Sudah banyak laki-laki yang meminangnya, namun Zahrana menolaknya dengan halus.

Di sinilah konflik batin Zahrana mulai timbul, antara menuruti keinginan orang tua atau mengejar cita-cita. Sebenarnya Zahrana sudah mengalah. Ia tak menerima tawaran jadi dosen di UGM. Alasannya karena orang tuanya yang tinggal di Semarang tidak mau jauh. Zahranapun memilih mengajar di sebuah universitas di Semarang. Ia tetap bisa tinggal bersama orang tuanya. Zahrana juga mengalah pada orang tuanya hingga ia tidak mengambil tawaran beasiswa S3 di negeri China.

Selain membentuk konstruksi masyarakat akan suatu hal, film juga merupakan rekaman realitas yang tumbuh dan berkembang dalam masyarakat dan kemudian memproyeksikannya ke atas layar (Sobur, 2006: 127). Begitu pula halnya dengan masalah mengenai perempuan yang selalu menarik untuk dibicarakan dan tidak akan pernah ada habisnya untuk dibahas. Pandangan masyarakat mengenai perempuan sebagian besar juga terbentuk oleh apa yang selama ini digambarkan oleh media massa, terutama sinema atau film. Film Cinta Suci Zahrana ini mendiskriminasikan tentang peran, status dan tanggung jawab seorang perempuan.

Film in menceritakan tentang seorang perempuan yang ambisius di bidang prestasi dan akademik. Namun semua jerih payah dan prestasi membanggakan tersebut sedikitpun tidak membuat kedua orang tuanya bangga, terutama sang ayah. Ayah Zahrana ini tidak menginginkan sederetan prestasi yang dia dapatkan, melainkan ia hanya ingin melihat anak perempuannya tersebut duduk bersanding di pelaminan dan segera dapat meminang cucu. Sehingga disinilah terjadi konflik batin yang begitu luar biasa yang dirasakan Zahrana, ketika ia sedang merasakan puncak kesuksesannya dalam bidang prestasi dan akademik. Zahrana menyadari bahwa di usianya sudah sangat berumur tersebut memang sudah selayaknya untuk menikah, sehingga ia menyesal kenapa dulu sering menolak lamaran lelaki dengan alasan masih ingin belajar dulu, mengejar karir akademik.
Film ini mendukung konsep patriarki, konsep yang mengacu pada satu kondisi bahwa segala sesuatu diterima secara fundamental dan universal sebagai dominasi kaum laki-laki dimana dalam film ini ayah Zahrana menjadi actor yang dominan. Untuk memahami bagaimana perbedaan gender telah melahirkan ketidakadilan gender, diantaranya dapat dikaji melalui berbagai ekspresi manifestasi ketidakadilan, terutama terhadap perempuan yang ada di masyarakat, yakni misalnya adanya bentuk-bentuk : Stereotip feminitas, Domestikisasi (Domestication) atau Pengiburumahtanggaan (Housewifization) perempuan, marginalisasi dan subordinasi perempuan, beban kerja perempuan yang lebih berat, serta kekerasan dan pelecehan seksual. Adapun factor penyebab terbesar dari hadirnya konsepsi ideology gender yang menyebabkan ketidakadilan tersebut, adalah konstruksi "ideology patriarki" yang ada, berkembang, diyakini dan diinternalisasikan dari generasi ke generasi, dalam dimensi ruang waktu yang cukup panjang di masyarakat (Kasiyan, 2008:44-46). Jika dilihat dalam arti harfiahnya "patriarki" memuat pengertian sebagai kepemimpinan para ayah (the role of fathers).

Isu gender menjadi agenda penting dari semua pihak, karena realitas perbedaan gender yang berimplikasi pada perbedaan status, peran dan tanggung jawab antara manusia lakilaki dan perempuan seringkali menimbulkan apa yang disebut dengan ketidakadilan gender atau diskriminasi maupun penindasan. Ketidakadilan ini dapat terjadi di berbagai bidang kehidupan, baik dalam wilayah domestik maupun publik, dalam bidang pendidikan, kesehatan, keamanan, ekonomi, politik, maupun pembangunan secara lebih luas. (Inayah Rohmaniyah, 2009:209)

Lalu, bagaimana perempuan direpresentasikan dalam film Cinta Suci Zahrana karya Chaerul Umam yang diangkat berdasarkan novel karya Habiburahman ElShirazy dan bagaimana kekuasaan laki-laki dimainkan dalam film ini menjadi pembahasan dalam penelitian. 


\section{Kajian Teori}

\section{Film dan Gender}

Film memiliki potensi untuk mempengaruhi khalayaknya. Dalam banyak penelitian tentang dampak film terhadap masyarakat, hubungan antar film dan masyarakat selalu dipahami secara linier. Artinya, film selalu mempengaruhi dan membentuk masyarakat berdasarkan muatan pesan (message) dibaliknya, tanpa pernah berlaku sebaliknya/ Tapi kritik yang muncul terhadap perspektif ini ddidasarkan atas argumen bahwa film adalah potret dari masyarakat dimana film dibuat. film selalu merekam realitas yang tumbuh dan berkembang dalam masyarakat dan kemudian memproyeksikannya ke atas layar menurut Irawanto 1999 hal. 14 dalam Alex Sobur (2009). Benar adanya sebuah film terkadang dapat mempengaruhi khalayaknya dalam hal ini adalah mereka yang menonton. Baiknya sebuah film dapat memberikan pengetahuan baru bagi masyarakat tapi buruknya tandatanda dalam film yang ditelan mentah-mentah bisa menyesatkan.

Masih menurut Irawanto dalam Alex Sobur (2009:17) Graeme Turner menolak perspektif tersebut yang melihat film sebagai refleksi masyarakat. makna film sebagai representasi dari realitas masyarakat, bagi Turner, berbeda dengan film sekedar sebagai refleksi dari realitas. Sebagai refleksi dari realitas, film sekedar "memindah" realitas ke layar tanpa mengubah realitas itu.

Sementara itu, menurut Van Zoest film merupakan bidang kajian yang amat relevan bagi analisis struktural atau semiotika. seperti yang pernah dia ungkapkan film dibangun dengan tanda-tanda semata. Tanda-tanda itu termasuk berbagai sistem tanda yang bekerja sama dengan baik untuk mencapai efek yang diharapkan. Rangkaian gambar dalam film menciptakan imaji dan sistem penandaan. Masih menurut van Zoest. bersamaan dengan tanda-tanda arsitektur. terutama indeksial. pada film terutama digunakan ikonis, yakni tanda-tanda yang menggambarkan sesuatu. Ciri gambar gambar film adalah persamaannya dengan realitas yang ditunjuknya. gambar dinamis dalam film merupakan ikonis bagi realitas yang dinotasikan.

Pada tingkat penandaan, film adalah teks yang memuat serangkaian citra fotografi yang mengakibatkan adanya ilusi gerak dan tindakan dalam kehidupa nyata. Pada tingkat petanda, film merupakan cermin kehidupan metaforis. Jelas bahwa topik dari film merupakan cermin kehidupan semiotika media karena dalam genre film terdapat signifikansi yang ditanggapi orang-orang masa kini dan melalui film mereka mencari rekreasi, inspirasi dan wawasan pada tingkat interpretant. (Danesi, 2010:134)

Dalam John Storey (2008:85) dengan gaya gramscian, Gledhill menganjurkan sebuah pemahaman mengenai hubungan antara penonton dan teks film sebagai salah satu 'negosiasi'. Ditegaskan bahwa negosiasi bisa dianalisis pada tiga level berbeda: khalayak,teks, institusi. Penerimaan merupakan momen negosiasi yang paling radikal, sebab yang paling bervariasi dan tidak bisa diprediksi. Sebagaimana ia tegaskan, situasi menonton dan membaca memengaruhi makna dan kesenangan akan sebuah karya dengan mengajukan serangkaian determinasi ke dalam pertukaran kultural, yang secara potensial resisten atau kontradiktif, yang muncul dari perbedaan kondisi kultural dan sosial pembaca atau penonton menurut kelas, gender, ras, usia, sejarah pribadi dan seterusnya.

Intervensi posfeminis ke dalam arena teori media dan film merupakan hasil pertumbuhan dan perkembangan keterlibatan feminisme, baik di dalam wacana media maupun wacana film. Feminis telah lama bertemu dalam perkembangan praktik feminsi di dalam area produksi dan kesarjanaan film. Dalam prosesnya, mereka telah memeriksa bahawa film dengan pandangan untuk mendemistifikasi berbagai asumsi tentang beroperasinya kebanyakan teori media dan film. Intervensi feminisme juga mencoba untuk menelaah cara di mana ideologi patriarki dan formasi sosial masyarakat patriarkial dipelihara melalui wacana media dan film. (Ann Brooks, 1997:245) 


\section{Ketidakadilan Gender}

Mengapa gender sebagai alat analisis sosial dan sekaligus sebagai sebuah kesadaran menjadi agenda yang penting dipromosikan? Perbedaan gender tidak akan menjadi perhatian dan menjadi bahan pertimbangan penting kalau saja tidak membawa dampak yang merugikan bagi kehidupan manusia, terutama manusia perempuan. Konsep gender menjadi penting karena perbedaan gender telah melahirkan sejarah panjang ketidakadilan sosial dalam masyarakat dan bahkan dalam kebijakan pemerintah. Sejarah perbedaan gender yang dimulai sejak manusia terlahir terjadi melalui proses yang panjang. Perbedaan tersebut dikonstruksi, dibentuk, disosialisasikan dan diperkuat melalui ajaran keagamaan maupun Negara. (Mansour Faqih, 1996:9) Perbedaan gender bahkan menciptakan ideologi gender yang diwarnai oleh pandangan bahwa kedudukan laki-laki lebih tinggi di atas perempuan. (Nunuk Prasetyo Murniati, 2004: xix) yang juga diperkukuh melalui agama dan tradisi. Melalui ritual keagamaan dan pembekuan narasi keagamaan yang dikontruksi, ideologi gender ditransmisi dan diperkuat dari satu generasi ke generasi berikutnya.

Ideologi gender memberikan dampak yang signifikan terhadap perkembangan agama tetapi juga dipengaruhi atau mendapatkan legitimasi dari tafsir agama. Dampak terburuk dari pendelegetimasian ini adalah diyakininya perbedaan gender sebagai ketentuan Tuhan atau takdir yang final, dan pada akhirnya, tidak mudah bagi masyarakat untuk membedakan antara ketentuan Tuhan yang sesungguhnya dentgan konstruksi yang dibangun oleh manusia secara sosial. Ideologi gender telah membentuk budaya patriarkal di masyarakat dan menciptakan male dominated culture, budaya yang didominasi oleh dan mengutamakan laki-laki sehingga memunculkan ketidakadilan.

Begitu pula seperti apa yang dicatat oleh Lisa Taylor (1995), amat penting kiranya mengenali bahwa kaum perempuan bukan sekedar objek pasif dari 'ideologi patriarkal' yang monolitik, melainkan makhluk yang secara ,aktif turut serta dalam resistensi dan perjuangan dalam kehidupan sehari-hari mereka. (John Storey, 2008:83)

Ketidakadilan gender muncul di berbagaiaspekkehidupandalambermasyarakat dan bernegara, bahkan beragama, di seluruh lini dan wilayah. bentuk ketidakadilan gender bermacam-macam tergantung pada struktur ekonomi dan organisasi sosial dari masyarakat tertentu dan pada budaya dari kelompok tertentu di masyarakat tersebut. (Judith Lorber, 2001:5)

\section{Teori Sudut Pandang (Standpoint Theory)}

Teori sudut pandang mengkaji bagaimana keadaan individu mempengaruhi aktivitas individu dalam memahami dan membentuk dunia social. Permulaan untuk memahami pengalaman bukanlah kondisi social, ekspektasi peran, atau definisi gender, tetapi cara khusus dimana individu membentuk kondisi tersebut dan pengalaman mereka didalamnya. Bagaimana pun juga, pandangan feminis bukan hanya lokasi social dan tidak juga diberikan secara otomatis karena menjadi perempuan: "pandangan diperoleh-didapatkan melalui refleksi kritis pada relasi kekuatan dan dengan menarik semangat yang diperlukan dalam membentuk sikap mental oposisi."

Epistemologis sudut pandang memperhitungkan keragaman dalam komunikasi wanita dengan memahami perbedaan sifat-sifat menguntungkan yang dibawa oleh wanita ke dalam komunikasi dan berbagai cara dalam pemahaman tersebut yang mereka jalankan dalam prakteknya. Teori sudut pandang menjawab pandangan-pandangan esensialis terhadap wanita, misalnya, dengan cara memperkenalkan pentingnya agen individu dalam menginterpretasikan dan mengaplikasikan pemahaman tertentu tentang dunia social. Teori sudut pandang juga memperkenalkan elemen kekuatan terhadap permasalahan identitas. Individu yang tunduk atau tersisih melihat dunia melalui beragam sudut pandang, mereka mengalami dan memahaminya dari sifat mereka yang menguntungkan dan mereka juga melihatnya dari sudut pandang mereka yang punya 
kekuatan. (Littlejohn dan Karen A Foss, 2009:135-136)

Teori sudut pandang juga mengkritik dominasi laki-laki dan ideology patriarki. Teori ini menempatkan perempuan dalam konteks kapitalisme: pembagian kerja, pekerjaan rumah yang gratis, tanggungjawab reproduktif, tidak berdayanya perempuan di dalam masyarakat dan lainya. Bersamaan dengan muted group theory, perempuan membagi pengalaman dalam teori sudut pandang untuk mendapatkan hak-hak istimewa mereka dalam tujuannya menjadi orang yang berada di luar maupun bagian dari masyarakat yang didominasi lakilaki (Krolokke, 2006:32).

\section{Analisis Semiotika}

Semiotika adalah suatu ilmu atau metode analisis untuk mengkaji tanda. Tandatanda atau perangkat yang kita pakai daalam upaya mencari jalan di dunia ini, di tengahtengah manusia dan bersama-sama manusia. Semiotika dalam istilah Barthes, semiology, pada dasarnya hendak mempelajari bagaimana kemanusiaan (humanity) memaknai hal-hal (things). Memaknai (to signify) dalam hal ini tidak dapat mencampuradukkan dengan mengkomunikasikan (to communicate). Memaknai berarti bahwa objek-objek tidak hanya membawa informasi, dalam hal mana objek-objek itu hendak berkomunikasi, tetapi juga mengkonstitusi system dari tanda (Barthes dalam Sobur, 2006:15).

Semiotika berusaha menjelaskan jalinan tanda atau ilmu tentang tanda, secara sistematik menjelaskan esensi, ciri-ciri dan bentuk suatu tanda, serta proses signifikansi yang menyertainya. Umberto Eco, jauh-jauh hari sudah menjelaskan bahwa tanda dapat dipergunakan untuk menyatakan kebenaran sekaligus juga kebohongan.

Teknik analisis data yang digunakan dalam penelitian ini adalah analisis semiotic yang dikembangkan Roland Barthes. Telaah tentang genre pada media yang dilihat dari sudut semiotika diawali oleh Roland Barthes pada tahun 1950-an. Barthes menerapkan teori tanpa dasar pada analisis di berbagai jenis tontonan media dan genre dan menunjukkan bagaimana hal ini bisa menampilkan budaya pop sebagai pabrik pengalihan perhatian yang besar, ditujukan untuk membongkar bentuk-bentuk seni dan pembentukan makna tradisional (Danesi, 2010: 27-28). Semiotika fokus pada bagaimana makna diciptakan dan disampaikan melalui teks khususnya melalui dialog dalam suatu narasi, sehingga menitikberatkan pada tanda yang ditemukan dalam teks.

Menurut Hoed, Teori Semiotik Barthes hampir secara harfiah diturunkan dari teori bahasa menurut de Saussure. Setidaknya ada dua konsep yang dikembangkan Barthes yang relevan kaitan dengan semiotic. Yang pertama adalah konsep hubungan sintagmatik dan paradigmatic dan kedua adalah konsep denotasi dan konotasi Hoed, 2011:9-11).

Sistem kedua ini oleh Barthes disebut dengan konotatif, yang di dalam Mythologies-nya secara tegas ia bedakan dari denotatif atau system pemaknaan tataran pertama. Barthes menciptakan peta tentang bagaimana tanda bekerja (Cobley \& Jansz dalam Sobur, 2006:69).

\begin{tabular}{|l|l|}
\hline 1. Signifier (penanda) & 2. Signified (petanda) \\
\hline $\begin{array}{l}\text { 3. Denotative sign } \\
\text { (tanda denotatif) }\end{array}$ \\
\hline $\begin{array}{l}\text { 4. CONNOTATIVE } \\
\begin{array}{l}\text { SIGNIFIER } \\
\text { (PENANDA KONOTATIF) }\end{array}\end{array}$ & $\begin{array}{l}\text { 5. CONNOTATIVE } \\
\text { SIGNIFIED (PETANDA } \\
\text { KONOTATIF) }\end{array}$ \\
\hline \multicolumn{2}{|l|}{ 6. CONNOTATIVE SIGN (TANDA KONOTATIF) } \\
\hline
\end{tabular}

Pada dasarnya, ada perbedaan antara denotasi dan konotasi dalam pengertian secara umum serta denotasi dan konotasi yang dimengerti oleh Barthes. Dalam pengertian umum, denotasi biasanya dimengerti sebagai makna harfiah, makna yang "sesungguhnya" bahkan kadang kala juga dirancukan dengan referensi atau acuan. Proses signifikasi yang secara tradisional disebut sebagai denotasi ini biasanya mengacu kepada penggunaan bahasa dengan arti yang sesuai dengan apa yang terucap. Akan tetapi, di dalam semiology Roland barthes dan para pengikutnya, denotasi merupakan system signifikasi tingkat pertama, sementara konotasi merupakan tingkat kedua. Dalam hal ini, denotasi justru lebih 
diasosiasikan dengan ketertutupan makna. Dalam kerangka Barthes, konotasi identic dengan operasi ideology, yang disebutnya sebagai 'mitos' dan berfungsi untuk mengungkapkan dan memberikan pembenaran bagi nilai-nilai dominan yang berlaku dalam suatu periode tertentu. (Budiman dalam Sobur, 2006:70-71).

\section{Pembahasan}

Setelah menganalisis data berupa scene dari film Cinta Suci Zahrana dengan menggunakan teknik analisis data semiotik yang dikembangkan Roland Barthes. Dalam hal ini penulis berusaha mencari makna denotasi, konotasi dan mitos yang bisa merepresentasikan perempuan dalam film Cinta Suci Zahrana.

\section{Denotasi}

Film ini menggambarkan mengenai kisah seorang perempuan yang banyak mendapatkan prestasi, penghargaan dan berpendidikan tinggi. Namun dalam film ini diceritakan bahwa di usianya yang ke 34 tahun tokoh utama (Zahrana) belum mendapatkan jodoh. Sehingga membuat kedua orang tuanya merasa malu karena terdapat pembicaraan yang tidak enak tentang anaknya. Film ini lebih banyak menggambarkan bagaimana seorang perempuan yang berusaha mencari jodoh. Karena sebelumnya terjadi konflik batin dengan kedua orang tuanya yang merasa tidak senang dengan kondisi Zahrana saat ini, meskipun ia memiliki prestasi dan karir bagus.

Ditengah jalan ia bertemu dengan bu Karsi yang sedang menggendong anak Suti, Suti merupakan teman SMA Zahrana. $\mathrm{Bu}$ Karsi menyampaikan bahwa Suti sudah menikah sejak 4 tahun lalu dan saat ini baru saja memiliki anak. Orang tuanya sangat senang dengan kehadiran anak Suti. Lalu Zahrana berpikir bahwa yang ditunggu-tungu oleh ayahnya adalah perikahan dan memiliki keluarga layaknya Suti.

Proses lamar-melamar dan usaha dalam mencari jodoh dominan tergambar dalam setiap adegannya. Zahrana merupakan gadis desa yang berasal dari Demak, yang sebelumnya mengajar di salah satu Universitas di Semarang. Namun karir yang bagus tersebut ia tinggalkan karena menolak lamaran dari atasannya pak Sukarman, kemudian Zahrana memilih untuk menjadi guru di pesantren. Berharap disanalah ia akan mendapatkan jodohnya. Ia pasrah dengan kondisinya saat ini.

Setelah sekian lama Zahrana mencoba untuk mencari jodoh, namun hingga kini dia belum mendapatkannya. Bapaknya mulai jatuh sakit, karena memikirkan Zahrana yang belum menemukan jodohnya. Dia berbicara kepada kedua orangtuanya, dan menangis pasrah agar yang menentukan jodoh baginya adalah bapaknya. Meskipun Zahrana sudah terlalu banyak menyenangkan orang tua, namun mereka belum merasakan kebahagiaan yang berarti jika Zahrana belum mendapatkan jodoh. Zahrana masuk ke kamar bapaknya dan menunjukkan surat bahwa ia telah diterima menjadi guru di sebuah SMK, dan ia berharap disana ia akan mendapatkan jodohnya. Bapaknya sudah mulai sakit-sakitan, ia berharap sebelum kepergiannya Zahrana bisa menikah. Itulah permintaan terakhir dari kedua orang tuanya, meskipun Zahrana sudah banyak prestasi yang bisa membuat keduanya senang. Namun melihat pernikahan Zahrana lah yang paling mereka tunggu. Zahrana menangis dan menyerahkan pilihan jodohnya kepada bapaknya.

\section{Konotasi}

Makna konotasi dalam film ini adalah tentang upaya menemukan jodoh bagi perempuan dan menggambarakan bahwa sebanyak apapun prestasi yang didapatkan perempuan, tidak akan berarti jika dia belum bisa berumah tangga. Prestasi merupakan penghargaan atas sesuatu yang dicapai seseorang. Dimana prestasi adalah hasil dari usaha yang ia lakukan. Prestasi merupakan hasil nyata dari puncak pengembangan potensi diri. Prestasi hanya dapat diraih dengan mengerahkan segala kekuatan, kemampuan dan usaha yang ada dalam diri kita. Selain itu prestasi bisa menjadi sebuah kebanggaan. Dalam tokoh Zahrana ini digambarkan sebagai perempuan yang mendapatkan banyak 
prestasi, namun bapaknya merasa tidak begitu menyukai apa yang diperoleh anaknya tersebut.

Pendidikan dan prestasi yang diraih tidak menjadi penting ketika perempuan belum bisa membangun rumah tangga atau menikah. Seolah tidak peduli dengan gelar yang diraih anaknya, bapak Zahrana justru merasa malu dengan apa yang diraih anaknya saat ini. Ia hanya ingin Zahrana segera menikah agar bisa membanggakan kedua orangtuanya.

Bagi aliran feminis eksistensialis Perempuan adalah Liyan (the other) karena perempuan bukanlah laki-laki. Laki-laki adalah bebas, makhluk yang menentukan dirinya sendiri yang mendefinisi makna eksistensinya. Perempuan adalah Liyan (the other), objek yang tidak menentukan makna eksistensinya sendiri. Jika perempuan ingin menjadi diri, suatu subjek, perempuan, seperti juga laki-laki, harus mentransedensi definisi, label dan esensi yang membatasi eksistensinya. Perempuan harus menjadikan dirinya sebagai apa yang diinginkannya (Rosemarie, 2010:9).

Sementara itu kehadiran anak menjadi isyarat bahwa untuk menjadi perempuan yang lengkap ialah dapat memiliki anak. Kehadiran anak dalam keluarga merupakan sebuah pelengkap kebahagiaan dalam bahtera rumah tangga. Dan kehadiran cucu merupakan kebahagian juga kebanggaan bagi orang tua.

Bagi orang yang sudah berada di usia produktif, pembicaraan mengenai jodoh akan menjadi pembicaraan yang penting. Terlebih jika sudah melampui usia produktif dan belum menikah. Bagi perempuan sebutan perawan tua perlahan menempel dalam diri mereka. Seperti yang dialami Zahrana dalam film ini, bahwa sebutan tersebut telah disematkan dalam dirinya. Sehingga dorongan untuk menikah begitu kuat, bahkan menikah dengan orang yang usianya jauh lebih tua darinya pun Zahrana terima. Kedua orangtua Zahrana sangat menginginkan ia segera menikah, tidak penting apa yang didapatkan Zahrana sebelumnya.

Prestasi, karir dan pendidikan yang tinggi tidaklah cukup bagi mereka. Pernikahan bagi kedua orangtuanya juga sebagai penutup rasa malu atas apa yang disampaikan masyarakat kepada mereka tentang Zahrana. Zahrana berada pada posisi yang sangat tertekan, diusianya yang sudah mulai menapak di usia 34 tahun, namun ia belum mendapatkan jodoh. Ia memasrahkan jodohnya sesuai kehendak bapaknya.

Menurut Dorothy Kauffman McCall, opresi perempuan oleh laki-laki unik karena dua alasan: pertama, tidak seperti opresi ras dan kelas, opresi terhadap perempuan merupakan fakta historis yang saling berhubungan, suatu peristiwa dalam waktu yang berulangkali dipertanyakan dan diputarbalikkan. Perempuan selalutersubordinasilaki-laki. Kedua, perempuan telah menginternalisasikan cara pandang asing bahwa laki-laki adalah esensial dan perempuan tidak esensial (Rosemarie, 2010).

\section{Mitos}

Ada beberapa mitos dalam film Cinta Suci Zahrana ini, bagaimana representasi perempuan dibangun melalui ideology patriarki. Ideologi gender telah membentuk budaya patriarkal di masyarakat dan menciptakan male dominated culture, budaya yang didominasi oleh dan mengutamakan lakilaki sehingga memunculkan ketidakadilan. Film ini menggambarkan tentang perempuan yang memiliki prestasi dan berpendidikan tinggi, namun apa yang ia miliki belum mampu membuat dirinya bisa memilih jalan hidupnya.

Penafisiran mengenai prestasi tidak serta merta membuat kebanggan bagi setiap orang tua, terlebih ia seorang perempuan. Suatu fenomena budaya yang memarjinalkan dan menomorduakan kaum perempuan dengan alasan bahwa kaum perempuan tidak perlu memiliki kedudukan, sehingga menjadikan kehidupan perempuan seolah tidak penting dan ditekan atau tidak bebas. Film ini menunjukkan mitos bahwa sebaikbaik perempuan ialah yang dapat menjadi ibu rumah tangga yang baik. Bukan sebuah prestasi dan gelar yang tinggi. Selain itu, mengenai pendidikan, perempuan selalu dinomorduakan dari pada laki-laki. Dengan alasan, seorang perempuan tidak boleh dilepas tanpa muhrim. 
Dalam aliran feminis liberal John Stuart Mill dalam Rosemarie (2010:24) berpendapat bahwa setelah perempuan mendapat pendidikan penuh dan hak pilih, kebanyakan perempuan akan memilih untuk tetap berada di dalam ranah pribadi, tempat fungsi primer mereka adalah untuk "memperindah dan mempercantik diri", daripada untuk mendukung kehidupan. Ia juga menentang asumsi di dalam masyarakat mengenai kecenderungan perempuan untuk lebih memilih perkawinan dan tugas sebagai ibu daripada karier dan pekerjaan. Bahkan , Taylor menegaskan, bahwa perempuan yang sudah menikah tidak dapat menjadi orang yang sungguh-sungguh setara dengan suaminya, kecuali jika ia mempunyai kepercayaan diri dan rasa bahwa ia berhak atas kesetaraan itu yang muncul dari kontribusi "materi untuk menopang keluarga".

Perempuan harus melihat perkawinan dan motherhood sebagai bagian dari kehidupannya. Dalam arti bahwa perempuan yang benar-benar menjadi perempuan ialah perempuan yang bisa melahirkan dan mengasuh anak. Bagi orang tua kehadiran cucu merupakan saat yang dinanti-nanti, Dengan kehadiran anak dalam suatu keluarga, orang tua akan merasa senang karena sudah ada yang akan meneruskan apa yang menjadi cita-cita dan harapan mereka.

Menurut Judith Lober (2001:5) ketidakadilan gender muncul di berbagai aspek kehidupan dalam bermasyarakat dan bernegara, bahkan beragama, di seluruh lini dan wilayah. Bentuk ketidakadilan gender bermacam-macam tergantung pada struktur ekonomi dan organisasi sosial dari masyarakat tertentu dan pada budaya dari kelompok tertentu di masyarakat tersebut.

Sebutan perawan tua menjadi penyakit social yang kerap dirasakan oleh perempuan saat ini, sehingga ini menimbulkan perasaan malu ketika berada ditengah masyarakat. Malu pada ejekan masyarakat akan menyempitkan dada. Perempuan akan terdorong dalam ruang kosong dan kehampaan. Dalam hal ini menurut Dorothy Kauffman McCall Dalam Rosemarie (2010), opresi perempuan oleh laki-laki unik karena dua alasan: pertama, tidak seperti opresi ras dan kelas, opresi terhadap perempuan merupakan fakta historis yang saling berhubungan, suatu peristiwa dalam waktu yang berulangkali dipertanyakan dan diputarbalikkan. Perempuan selalu tersubordinasi laki-laki. Kedua, perempuan telah menginternalisasikan cara pandang asing bahwa laki-laki adalah esensial dan perempuan tidak esensial.

Selain itu, perempuan di Indonesia secara umum bukanlah pengambil keputusan di keluarga maupun di tataran masyarakat. Jajak pendapat yang dilakukan oleh UNDP tentang perilaku dan persepsi terhadap partisipasi perempuan secara sosial, ekonomi dan politis mengungkapkan bahwa 77,6 persen responden laki-laki maupun perempuan memandang bahwa laki-laki harus menjadi pengambil keputusan dan pemimpin di kalangan masyarakat, sementara 95 persen responden mengatakan bahwa laki-laki harus menjadi kepala rumah tangga. Sembilan puluh empat (94) persen dari responden merasa bahwa perempuan tidak boleh bekerja tanpa ijin dari suami mereka. Temuan dalam survey itu menunjukkan bahwa bias gender dalam pengetahuan, perilaku dan praktik di tengahtengah masyarakat terus bercokol secara nasional di kalangan masyarakat Indonesia (UNDP Indonesia,2010:22).

\section{Penutup}

Dalam film Cinta Suci Zahrana ini membentuk beberapa representasi mengenai perempuan, bahwa pendidikan dan prestasi yang diraih tidak menjadi penting ketika perempuan belum bisa membangun rumah tangga atau menikah. Ideologi gender telah membentukbudayapatriarkaldimasyarakatdan menciptakan male dominated culture, budaya yang didominasi oleh dan mengutamakan lakilaki sehingga memunculkan ketidakadilan. Aktor yang mendominasi dalam film ini adalah Bapak Zahrana, bagaimana ia meneguhkan kekuasaannya dalam menentukan bagaimana anaknya harus berlaku.

Hasil pembahasan diatas juga memperteguh bahwa Teori sudut pandang 
makin menggambarkan dominasi laki-laki dan ideologi patriarki. Teori ini menempatkan perempuan dalam konteks kapitalisme: pembagian kerja, pekerjaan rumah yang gratis, tanggungjawab reproduktif, tidak berdayanya perempuan di dalam masyarakat dan lainnya. Penafisiran mengenai prestasi tidak serta merta membuat kebanggan bagi setiap orang tua khususnya Bapak, terlebih ia seorang perempuan. Seperti yang dialami Zahrana dalam film ini.

Film ini menunjukkan mitos bahwa sebaik-baik perempuan ialah yang dapat menjadi ibu rumah tangga yang baik. Bukan sebuah prestasi dan gelar yang tinggi. Kemudian perempuan yang benar-benar menjadi perempuan ialah perempuan yang bisa melahirkan dan mengasuh anak. Dalam film ini Zahrana juga menerima sebutan sebagai perawan tua karena pada usia yang ke-34 tahun dia juga belum menikah.

Pada dasarnya, Islam memandang pernikahan sebagai sarana menggapai separuh kesempurnaan beragama. Hal ini sesuai dengan sabda Rasulullah Saw: "apabila seorang hamba telah berkeluarga, berarti dia telah menyempurnakan separuh (dari pengalaman ajaran) agamanya. Maka bertakwalah kepada Allah tehadap separuhnya yang lain" (HR. Thabrani)

Maka Islam dari pijakan hadis di atas bukan saja mensunnahkan nikah malah memotifasi dan menganjurkan pernikahan bagi yang sudah memenuhi persyaratan untuk menikah. Hal itu untuk memberikan jalan manusia memperoleh kebahagiaan hidupnya. Pernikahan adalah lembaga yang sah untuk membangun sebuah keluarga yang diterima oleh agama dan masyarakat, untuk menyempurnakan agama seseorang.

\section{DAFTAR PUSTAKA}

Brooks, Ann.1997. Posfeminisme dan Cultural Studies. Yogyakarta: Jalasutra

Danesi,Marcel. 2002. Understanding Media Semiotics. New York: Oxford University Press Inc
Fiske, John. 2007. Cultural and Communication Studies Cetakan ke$I V$. Yogyakarta: Jalasutra

Letty M Russel \& Clarkson JS.1996. Dictionary of Feminist Theology. Kentucky: Westminster John Knox Press

Littlejohn, Stephen W dan Karen A. Foss. (2011). Teori Komunikasi. Jakarta: Salemba Humanika.

Fakih, Mansour. 1996. Analisis Gender \& Transformasi Sosial. Yogyakarta: Pustaka Pelajar

Inayah Rohmaniyah. Gender dan Konstruksi Perempuan Dalam Agama. Jurnal Studi Ilmu-Ilmu Al-Qur'an dan Hadis Vol.10, No.2 Juli 2009

Krolokke, Charlotte. 2006. Gender Communication Theories \& Analyses. California: Sage Publications

Lorber, Judith. 2001. Gender Inequality: Feminist Theories and Politics. California: Roxbury

Nunuk Prasetyo Murniati. 2004. Getar Gender. Magelang: Indonesiatera Putnam Tong, Rosemarie. 2010. Feminist Tought. Yogyakarta: Jalasutra

Sobur, Alex. 2006. Semiotika Komunikasi. Bandung: Remaja Rosdakarya

Storey, John.2008. Cultural studies dan kajian budaya. Yogyakarta: Jalasutra

Kasiyan, Manipulasi dan Dehumanisasi Perempuan dalam Iklan, (Yogyakarta : Ombak, 2008) , hlm.44-46

UNDP. 2010. Partisipasi Perempuan dalam Politik dan Pemerintah. 